\title{
Brazilian organic sugarcane spirits: Physicochemical and chromatographic profile ${ }^{1}$
}

\author{
Cachaças orgânicas brasileiras: perfil físico-químico e cromatográfico
}

\author{
Felipe Cimino Duarte ${ }^{2}$, Maria das Graças Cardoso ${ }^{3 *}$, Wilder Douglas Santiago ${ }^{3}$, Ana Maria Resende \\ Machado $^{2}$ and David Lee Nelson ${ }^{2}$
}

\begin{abstract}
There has been a growing demand for products from organic agriculture for the food market. Brazil leads the production of sugarcane spirits and produces about 1.6 billion liters/year. New technologies have been sought throughout the supply chain to improve production, and organic raw material has been used in the production of sugar cane for the production of beverages. This study aimed to define the physicochemical and chromatographic profiles of eleven organic sugarcane spirits samples from various Brazilian states. The secondary components and contaminants were identified and quantified through physicochemical analyses, HPLC and gas chromatography (GC). A significant percentage of the organic sugarcane spirits samples contained concentrations of components that were above the limits required by the Ministry of Agriculture, Livestock and Provisioning (MAPA), specifically the esters (18.20\%), copper and dry extract $(9.10 \%)$. This contamination is caused by bad conditions employed during the production process, which are not in compliance with the good manufacturing practices determined and legislated by Brazilian law.
\end{abstract}

Key words: Identification. Quantification. Volatile Compounds. Ethyl carbamate.

\begin{abstract}
RESUMO - Ultimamente, no mercado de alimentos vem crescendo a demanda por produtos provenientes da agricultura orgânica. O Brasil lidera a produção de cachaça e produz cerca de 1,6 bilhões de litros/ano. Para a melhoria do produto, temse buscado novas tecnologias em toda a cadeia produtiva e utilizado matéria-prima orgânica na produção de cana-de-açúcar para a obtenção da bebida. O presente trabalho teve por objetivos traçar o perfil físico-químico e cromatográfico de onze amostras de cachaça orgânica provenientes de alguns estados brasileiros. Foram identificados e quantificados os componentes secundários e contaminantes por meio das análises físico-químicas, cromatografia líquida de alta eficiência (CLAE) e análises cromatográficas em fase gasosa (CG). Pelos resultados encontrados observou-se um percentual significativo das cachaças orgânicas pesquisadas, onde estas apresentaram parâmetros fora dos limites exigidos pelo Ministério da Agricultura, Pecuária e Abastecimento (MAPA), sendo encontrado valores inadequados de 18,20\% para ésteres, 9,10\% para cobre e extrato seco. Esta contaminação é acarretada pela má condução durante o processo pelos produtores, onde não estão observando as boas práticas de fabricação determinadas e/ou normatizadas pela legislação brasileira.
\end{abstract}

Palavras-chave: Identificação. Quantificação. Compostos voláteis. Carbamato de etila.

\footnotetext{
DOI: $10.5935 / 1806-6690.20170033$

*Autor para correspondência

Recebido para publicação em 14/02/2013; aprovado em 22/06/2016

${ }^{1}$ Projeto de pesquisa do primeiro autor apresentado no Programa de Pós-Graduação em Ciência dos Alimentos da Universidade Federal de Lavras (DCA/UFLA)

2Departameto de Ciências dos Alimentos, Universidade Federal de Lavras, Lavras-MG, Brasil, filipao_eng_alm@yahoo.com.br, anamrmachado@deii. cefetmg.br, dlnelson@ufmg.br

32Departamento de Química, Universidade Federal de Lavras/UFLA, Câmpus Universitário, Lavras-MG, Brasil, 37.200-000, mcardoso@dqi.ufla.br, wildaoquimica@msn.com
} 


\section{INTRODUCTION}

The organic sugarcane spirits are characterized by being produced without the addition of any pesticide type and/or additives of a chemical nature, because in such spirits only the use of organic products that occur in the planting of the sugarcane is allowed. When considering an organic system of agricultural production it is necessary to verify that the whole process adopts specific techniques with ecological principles of preservation of life and nature as foreseen in Law No. 10.831, of 12/23/2003 (BRASIL, 2003). The organic sugarcane spirits fall under the requirements specified by that law, as well as the sugarcane spirits from cultivations without pesticides (WOP). The sugarcane destined for the production of organic sugarcane spirits is cultivated under crop rotation, recycling of organic residues, green fertilizers, rockminerals, management and biological control of pests and diseases, always striving to maintain the soil fertility to supply the plant nutrition and their health and, with that, generate healthy products free from planted.

The characteristics of the organic sugarcane spirits differ those of the sugarcane spirits WOP and from the conventional, in that the sugarcane spirits WOP do not present the addition of chemical products in the soil cultivation, however some type of applied chemical product can be used in the plantation. In the sugarcane spirits of conventional cultivation, the cane is produced with the use of pesticides and synthetic pesticides, that can influence the soil negatively, unless correct administration of the dosages of those substances in the sugarcane plantations occurs and phytosanitary problems are avoided or excluded. In that process the acceleration of the maturation of the cane used for sugarcane spirit production by the addition of chemical products can also occur.

The commercialization of the sugarcane spirits of conventional cultivation is done on a wide scale, that provides low cost reduction in relation to the production of the organic sugarcane spirits, that requires higher care and control during its planting and for presenting a lower production yield because chemical compounds are not used as in the others (CARDOSO, 2013).

It is known that the production of sugarcane spirits in Brazil reaches the figure of 1.6 billion liters annually, representing $87 \%$ of the national production in relation to other drinks. The sugarcane spirits have good acceptance in foreign countries. In 2011, sugarcane spirits exports reached the figure of US\$ 17.3 million (APEX, 2012; SEBRAE, 2014). However, Sebrae (2014), Cardoso (2013) and Alcarde, Souza and Belluco (2010) indicate that the famous sugarcane spirits brands that dominate the market, both domestic and foreign, are in the hands of the large producers, while there are about 30 thousand small and medium producers. Many of them are devoted to the production of the drink in artisanal stills, therefore, the commercialization of the drink being restricted to the Brazilian market.

Few studies have been presented on organic sugarcane spirits. Thus, the formation of a physiochemical and chromatographic profiles of different samples of organic sugarcane spirits produced in some Brazilian states is justified due to the growing demand in the food sector for organic products divulging more relevant information to increase and improve the production of the drink.

This study sought to define the physicochemical and chromatographic profiles of eleven samples of organic sugarcane spirits from various Brazilian states. The secondary components and contaminants were identified and quantified through physicochemical analyses, HPLC and gas chromatography.

\section{MATERIALS AND METHODS}

\section{Obtaining samples}

The samples were acquired from cane spirit stores and the Central Market, in Belo Horizonte. To acquire the product, we observed that the stamp of certification identified the product as organic sugarcane spirits. The origin (State where produced) of the samples was not considered. Of the 11 studied samples, six were manufactured in Minas Gerais, one in Ceará, one in Paraná and three in Bahia (artesanal production).

In the conduction of the physiochemical and chromatographic profile of the different samples, the brand labels were removed from the sugarcane spirits that, soon afterwards, were poured into identical bottles. Subsequently, each bottle was numbered, aiming to analyze and profile them.

\section{Physico-chemical and chromatographic analysis}

In the of Liquor Physiochemical Analyses Laboratory of the Federal University of Lavras (UFLA) the analysis regarding the Alcohol content, Dry extract, Copper, Volatile acidity, Superior alcohols, Methanol, Furfural, Aldehydes and Esters was undertaken. The Analyses Methods for Fermented, Distilled, No-alcoholic Drinks and Vinegar established by the Regulation by MAPA (BRASIL, 2005) were adpoted for the tests with the researched samples. For the high-performance liquid chromatography (HPLC) and ethyl carbamate (EC) the method of Madrera and Valles (2009) and Park et al. 
(2007) modified by Anjos et al. (2011) and Santiago et al. (2014a) were used.

The gas phase chromatographic analysis of ethyl acetate and methyl, sec-butyl, propyl, isobutyl, butyl, and isoamyl alcohols were performed in the Departamento de Química do Centro Federal de Educação Tecnológica (CEFET-MG) in Belo Horizonte, MG, Brazil. Analytical grade reagents were used in all the physicochemical analyses; those used in the analysis of GC and HPLC were of chromatographic grade.

\section{Gas chromatography analysis}

The quantification of those compounds was carried out via analytical curve, preparing six concentration levels of the standards in $40 \%$ alcoholic solution. The apparatus used was an Agilent Technologies $6890 \mathrm{~N}$ gas chromatograph, with ion flame detector (FID). An INNOWAX (30 m; $0.32 \mathrm{~mm} ; 0.25 \mu \mathrm{m})$ column was used with a $1 \mu \mathrm{L}$ injection volume. Hydrogen was used as carrier gas, besides synthetic air and nitrogen gas. The chromatographic conditions were the following: initial temperature of $43{ }^{\circ} \mathrm{C}$ for four minutes, heating ramp of $14{ }^{\circ} \mathrm{C}$ per minute up to $100{ }^{\circ} \mathrm{C}$, remaining at that temperature for four minutes and a ramp of $5{ }^{\circ} \mathrm{C}$ per minute up to $180{ }^{\circ} \mathrm{C}$, remaining for two minutes. The injector temperature was $220^{\circ} \mathrm{C}$, detector temperature, $270{ }^{\circ} \mathrm{C}$ and the split ratio $20: 1$.

Linear regression was used in GC, plotting the relationship of the peak areas of the standards versus concentration. The detection and quantification limits were determined by standard dilutions to get a signal:noise ratio of 3 and 10, respectively. The straight line equations obtained for the analytical curves as well as the correlation coefficients are described in Table 1.

\section{Liquid chromatography analysis}

The identification and quantification of EC by HPLC was conducted according to the method of Anjos et al. (2011) and Santiago et al. (2014a), using external standardization with derivatization of the samples prior to HPLC analysis. The reagents employed for the analysis were the EC standard (Acros Organics), ethanol, propanol, hexane, hydrochloric acid, ethyl acetate, sodium acetate, HPLC grade acetonitrile (Merck), ultrapure water, and 9-xanthydrol (Acros Organics).

A stock EC solution was prepared at a concentration of $10 \mathrm{mg} \mathrm{L}^{-1}$ in ethyl acetate for the quantitative analysis. For the construction of the analytical curve, dilutions of the stock solution in $50 \%$ ethanol were performed to furnish work solutions at concentrations that varied from 5.0 to $160.0 \mu \mathrm{g} \mathrm{L}^{-1}$. The analytical curve presented six points; the linearity was verified through the linear regression method.

Sample derivatization was achieved in an amber flask with $4.0 \mathrm{~mL}$ of sugarcane spirits, to which was added $0.8 \mathrm{~mL}$ of $0.02 \mathrm{~mol} \mathrm{~L}^{-1}$ xanthydrol solution (prepared in propanol). After stirring, $0.4 \mathrm{~mL}$ of $1.5 \mathrm{~mol} \mathrm{~L}{ }^{-1} \mathrm{HCl}$ was added and stirring was continued for one minute. The mixture was kept at rest for 60 minutes and filtered through $0.45 \mu \mathrm{m}$ (Millipore) polyethylene membranes.

The EC analyses were conducted in a Shimadzu liquid chromatograph, equipped with two of high pressure LC-6AD pumps, a DGU-20A3 degasser, an automatic injector with autosampler (model SIL-10AF), a model CBM-20A interface, and a fluorescence detector (FLD; model RF-10AXL). The separations were achieved using an Agilent - Zorbax Eclipses AAA column (4.6 x 150 mm, $5 \mu \mathrm{m})$ connected to a Agilent - Zorbax Eclipses AAA 4Pack pre-column (4.6 x $12.5 \mathrm{~mm}, 5 \mu \mathrm{m})$.

The external standardization method was employed for EC quantification. The excitation and emission wavelengths used were 233 and $600 \mathrm{~nm}$, respectively. The flow rate used in the analysis was $0.75 \mathrm{~mL} \mathrm{~min}^{-1}$, and the injected sample and standards volumes were $20 \mu \mathrm{L}$. The mobile phase was composed of $20 \mathrm{mM}$ sodium acetate solution (Solvent A) and acetonitrile (Solvent B). The

Table 1 - Correlation coefficients of analytical curves obtained for the secondary alcohols and other compounds accompanied by the of detection and quantification limits

\begin{tabular}{lcccc}
\hline \multicolumn{1}{c}{ Componente } & $\mathrm{R}^{2}$ & Concentration range $\left(\mathrm{mg} 100 \mathrm{~mL} \mathrm{a. \textrm {a } ^ { - 1 }}\right)$ & $\mathrm{DL}\left(\mathrm{mg} 100 \mathrm{~mL} \mathrm{a. \textrm {a } ^ { - 1 }}\right)$ & $\mathrm{QL}\left(\mathrm{mg} 100 \mathrm{~mL} \mathrm{a} \cdot \mathrm{a}^{-1}\right)$ \\
\hline Ethyl acetate & 0.9961 & $2-250$ & 2.0 & 6.7 \\
Methyl alcohol & 0.9986 & $1-50$ & 1.03 & 3.4 \\
sec-Butyl Alcohol & 0.9992 & $1-30$ & 1.1 & 3.6 \\
Propyl alcohol & 0.9976 & $2-250$ & 2.3 & 7.6 \\
Isobutyl alcohol & 0.9981 & $2-250$ & 2.5 & 8.3 \\
Butyl alcohol & 0.9993 & $1-9$ & 1.7 & 5.6 \\
Isoamyl alcohol & 0.9992 & $2-250$ & 2.0 & 6.7 \\
\hline
\end{tabular}


elution was conducted in a gradient type system: 0 to 5 $\min (40-60 \% \mathrm{~B}) ; 5$ to $10 \mathrm{~min}(60-70 \% \mathrm{~B}) ; 10$ to $18 \mathrm{~min}$ $(70-80 \% \mathrm{~B}) ; 18$ to $19.5 \mathrm{~min}(80-90 \% \mathrm{~B}) ; 19.5$ to $25 \mathrm{~min}$ $(90-40 \% \mathrm{~B})$; and 25 to $30 \mathrm{~min}(40 \% \mathrm{~B})$.

The quantification of EC in the sugarcane spirit samples was conducted through the construction of an analytical curve obtained by linear regression $(\mathrm{y}=$ $10592.61 \mathrm{x}+8200.84$; where $\mathrm{y}=$ area of the peak and $\mathrm{x}=$ concentration of EC), correlating the area of the peak versus the concentration of the respective standard solution. The determination coefficient $\left(\mathrm{R}^{2}\right)$ obtained was 0.9998. The quantification (QL) and detection (DL) limits were estimated from the parameters obtained for the analytical curve, being calculated from the respective mathematical ratios: $\mathrm{QL}=10 \mathrm{SD} / \mathrm{m}$ and $\mathrm{DL}=$ $3 \mathrm{SD} / \mathrm{m}$ (where $\mathrm{SD}=$ estimate of the standard deviation of the regression line and $\mathrm{m}=$ angular coefficient of the calibration line) (HARRIS, 2008). More detailed data regarding the validation of the method proposed for the EC determination in sugarcane spirits can be verified in the work of Anjos et al. (2011), who carried out the validation and comparison of different methods for the analysis of that pollutant in the beverage, this being an application of the method already validated by that author. All of the samples were analyzed in duplicate, while the standard work solutions were analyzed in triplicate.

\section{RESULTS AND DISCUSSION}

The values obtained for physiochemical analyses are represented in Table 2. It can be observed that $36.40 \%$ of the samples were outside the standard recommended by MAPA as to the content of esters (18.20\%), copper $(9.10 \%)$ and the dry extract $(9.10 \%)$.

The results for the parameters of alcohol content, volatile acidity, higher alcohols, furfural, aldehydes and methanol were within the limits established by MAPA, corroborating various research works that evaluated sugarcane spirits produced from conventionally cultivated cane. In those works, high diversity in the results was also found, some with limits above those required by the legislation (BARCELOS et al., 2007; MIRANDA et al., 2008; PEREIRA et al., 2003; SOUZA et al., 2009; VILELA et al., 2007; ZACARONI et al., 2011).

The high ester content of the samples 01 and 02 can be explained by the fact that the studied drinks are aged, esterification reactions occurring during that period. Miranda et al. (2008) observed that, after 390 days of storage in a glass container, there was a $57 \%$ increase in the ester concentration. Those compounds increase due to the esterification reactions among alcohols and carboxylic acids that occur over time. However, if the compound is in high concentrations, it will lead to an undesirable and rich flavor in the drink (BARCELOS et al., 2007; CARDOSO, 2013; SANTIAGO et al., 2014b).

The high copper content in Sample 04 probably occurred due to the lack of sanitation of the still that, in most of the artisanal spirit distilleries, is constructed with that metal. During the distillation process of the drink, the acid vapors carry the basic copper carbonate $\left[(\mathrm{OH})_{2} \mathrm{CO}_{3}\right]$ (verdigris), formed on the internal walls of the stills, thus leading to the contamination of the product. Another factor that can contribute to the contamination by the metal is the

Table 2 - Results of physical and chemical analysis of organic sugarcane spirits

\begin{tabular}{|c|c|c|c|c|c|c|c|c|c|}
\hline Samples & $\begin{array}{l}\text { Copper } \\
\mathrm{mg} \mathrm{L}^{-1}\end{array}$ & $\begin{array}{c}\text { Dry Extract } \\
\qquad \mathrm{g} \mathrm{L}^{-1}\end{array}$ & $\begin{array}{c}\text { Alcohol Content } \\
(\%)\end{array}$ & Volatile Acidity* & $\begin{array}{l}\text { Total higher } \\
\text { alcohols* }\end{array}$ & Furfural* & Aldehyde* & Esters* & Methanol* \\
\hline 01 & 3.69 & 0.57 & 39.91 & 37.54 & 228.94 & 0.02 & 13.49 & 222.43 & $\mathrm{Nd}$ \\
\hline 02 & 2.79 & 0.70 & 39.75 & 71.63 & 312.03 & 0.27 & 21.37 & 221.18 & $\mathrm{Nd}$ \\
\hline 03 & 4.79 & 0.38 & 42.23 & 102.92 & 215.33 & 0.93 & 20.17 & 129.09 & $\mathrm{Nd}$ \\
\hline 04 & 5.33 & 0.25 & 41.23 & 59.98 & 179.91 & 0.08 & 19.35 & 196.19 & $\mathrm{Nd}$ \\
\hline 05 & 1.09 & 0.43 & 38.59 & 102.92 & 196.49 & 0.74 & 14.23 & 185.03 & $\mathrm{Nd}$ \\
\hline 06 & 2.72 & 0.18 & 43.05 & 43.52 & 218.98 & 0.04 & 22.58 & 194.03 & $\mathrm{Nd}$ \\
\hline 07 & 4.60 & 0.22 & 39.25 & 57.23 & 292.53 & 0.03 & 4.11 & 199.38 & $\mathrm{Nd}$ \\
\hline 08 & 4.09 & 0.26 & 39.58 & 75.80 & 264.91 & 0.10 & 21.46 & 55.12 & 2.75 \\
\hline 09 & 0.05 & 0.10 & 40.74 & 18.40 & 64.32 & 0.06 & 16.28 & 70.65 & 4.21 \\
\hline 10 & 1.04 & 0.19 & 39.06 & 43.68 & 286.80 & 0.01 & 21.46 & 40.26 & 8.63 \\
\hline 11 & 1.40 & 43.78 & 39.31 & 33.96 & 183.92 & 0 & 16.26 & 31.11 & 9.10 \\
\hline Legal limit $* *$ & 5.0 & 6.0 & $38-54.0$ & 150.0 & 360.0 & 5.0 & 30.0 & 200.0 & 20.0 \\
\hline
\end{tabular}

Note: $\mathrm{Nd}=$ not detected; $* \mathrm{mg}$ in $100 \mathrm{~mL}$ of anhydrous alcohol.**(BRASIL, 2005) 
incorrect cut-off of the fractions, using the drink head and heart fractions (CARDOSO, 2013).

Regarding the high content of the dry extract in Sample 11, an addition of sugar to the drink by the producer probably occurred. Under the current Brazilian legislation, the addition of up to $6 \mathrm{~g} \mathrm{~L}^{-1}$ of sugars is allowed for sugarcane spirits and cane liquor (BRASIL, 2005).

Table 3 shows the results of the analyses conducted by gas phase chromatography, which are consistent and close to those found by Gabriel et al. (2012), on studying the influences of two types of yeast (natural and commercial) used as raw material for the production of their organic sugarcane drink.

Figure 1 shows the chromatograms of Sample 11 (A) and the standards (B) of the alcohols and the ethyl acetate.
The butyl, sec-butyl and methyl alcohols, are sugarcane spirit pollutants and they should not be found and/or only detected in low values. No sample presented content above that permited for those pollutants.

The main factor for the formation of butyl alcohol in sugarcane spirits is the contamination by acetobutylic bacteria during the fermentation process. That contamination can be reduced by not leaving the sugar cane near stables and milking locations (CARDOSO, 2013; MAIA; CAMPELO, 2006).

The methyl alcohol content detected was below the limit established by the legislation. That result corroborates the current research that has been showing content below the allowed limit, that is $20 \mathrm{mg} 100 \mathrm{~mL}$ in $\mathrm{aa}^{-1}$ (BOGUSZ JUNIOR et al., 2006; MASSON et al., 2012; MIRANDA et al., 2006; PARAZZI et al., 2008).

Table 3 - Average results of gas chromatography analysis

\begin{tabular}{|c|c|c|c|c|c|c|c|c|}
\hline \multicolumn{9}{|c|}{ Concentration mg $100 \mathrm{~mL}$ of anhydrous ethyl alcohol (aa) ${ }^{-1}$} \\
\hline Sample & Ethyl acetate & Methyl alcohol & sec-Butyl Alcohol & Propyl alcohol & Isobutyl alcohol & Butyl alcohol & Isoamyl alcohol & $\begin{array}{l}\text { Higher } \\
\text { alcohols* }\end{array}$ \\
\hline 01 & $155.72 \pm 2.78$ & $<\mathrm{DL}$ & $4.56 \pm 0.91$ & $35.52 \pm 4.22$ & $49.85 \pm 5.02$ & $1.01 \pm 0.21$ & $134.81 \pm 2.98$ & 220.18 \\
\hline 02 & $154.73 \pm 1.23$ & $<\mathrm{DL}$ & $6.07 \pm 1.01$ & $49.92 \pm 5.01$ & $65.47 \pm 4.98$ & $2.8 \pm 0.21$ & $185.13 \pm 4.98$ & 300.52 \\
\hline 03 & $90.47 \pm 1.23$ & $<\mathrm{DL}$ & $3.3 \pm 0.24$ & $34.45 \pm 3.27$ & $47.4 \pm 3.67$ & $1.03 \pm 0.09$ & $129.06 \pm 4.89$ & 207.91 \\
\hline 04 & $139.16 \pm 1.54$ & $<\mathrm{DL}$ & $2.01 \pm 0.15$ & $26.98 \pm 2.54$ & $42.73 \pm 4.98$ & $1.72 \pm 0.09$ & $104.54 \pm 2.86$ & 174.25 \\
\hline 05 & $133.27 \pm 1.78$ & $<\mathrm{DL}$ & $5.71 \pm 0.87$ & $32.4 \pm 4.89$ & $45.02 \pm 2.98$ & $1.54 \pm 0.32$ & $110.86 \pm 4.65$ & 188.28 \\
\hline 06 & $133.87 \pm 1.45$ & $<\mathrm{DL}$ & $3.32 \pm 0.91$ & $31.78 \pm 2.35$ & $50.09 \pm 4.01$ & $1.65 \pm 0.12$ & $130.07 \pm 3.98$ & 211.94 \\
\hline 07 & $143.55 \pm 2.56$ & $<\mathrm{DL}$ & $2.92 \pm 0.35$ & $51.72 \pm 5.02$ & $62.15 \pm 3.25$ & $1.46 \pm 0.31$ & $172.05 \pm 5.09$ & 285.93 \\
\hline 08 & $39.05 \pm 0.67$ & $2.65 \pm 0.19$ & $3.28 \pm 0.54$ & $42.24 \pm 3.45$ & $53.84 \pm 4.01$ & $2.64 \pm 0.12$ & $158.08 \pm 3.87$ & 254.16 \\
\hline 09 & $60.86 \pm 0.89$ & $4.03 \pm 0.19$ & $1.28 \pm 0.76$ & $12.24 \pm 1.25$ & $13.75 \pm 1.90$ & $0.67 \pm 0.02$ & $35.09 \pm 0.98$ & 61.08 \\
\hline 10 & $27.78 \pm 0.45$ & $8.34 \pm 0.16$ & $6.4 \pm 0.97$ & $41.76 \pm 4.76$ & $62.19 \pm 4.87$ & $2.87 \pm 0.15$ & $171.06 \pm 2.96$ & 275.01 \\
\hline 11 & $22.39 \pm 0.21$ & $9.12 \pm 0.98$ & $3.66 \pm 0.78$ & $29.28 \pm 2.14$ & $40.28 \pm 3.19$ & $1.87 \pm 0.17$ & $106.09 \pm 2.65$ & 175.65 \\
\hline Norm** & 200 & 20 & 10 & - & - & 3 & - & 360 \\
\hline
\end{tabular}

Note: * Sum of higher alcohols: Propyl alcohol + 2-Methyl-propanol + Isoamyl alcohol; **Norm N 13 (BRASIL, 2005)

Figure 1 - Chromatogram of a standard solution (A) and Sample 11 (B) of alcohols and ethyl acetate
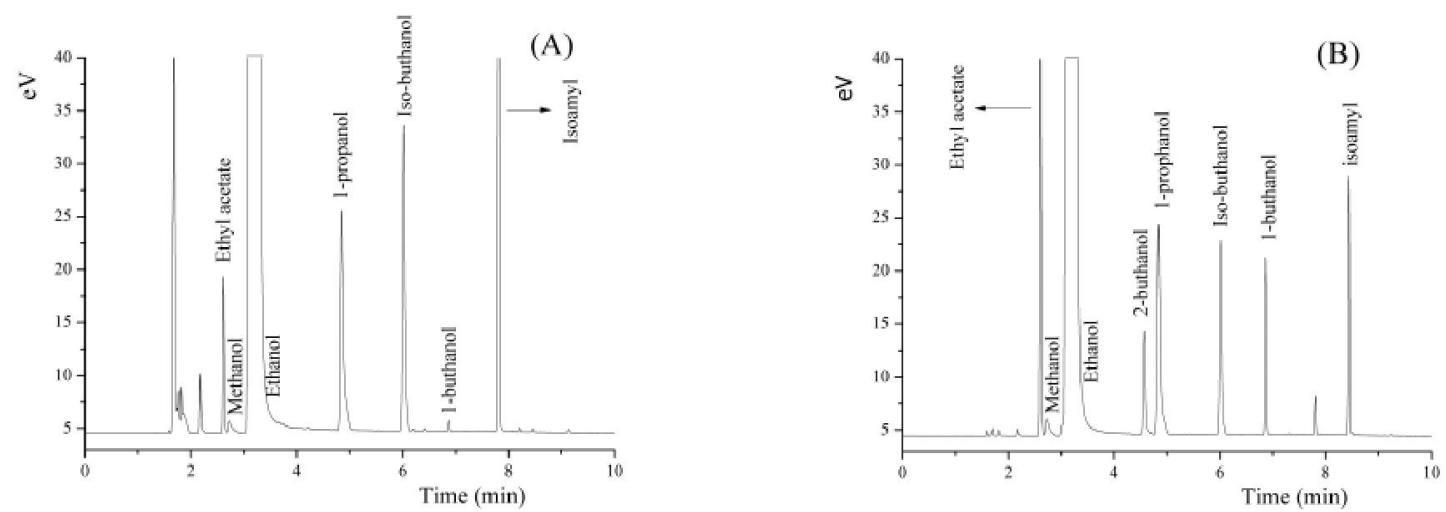
The values of the higher alcohols were obtained by the sum of the isobutyl, isoamyl and propyl alcohols. No sample exceeded the limit stipulated by the legislation. There was wide variation in the concentration of the higher alcohols, covering a wide range with the minimum from 61.08 to $300.52 \mathrm{mg} 100 \mathrm{~mL}$ in $\mathrm{aa}^{-1}$, corroborating those presented by Barcelos et al. (2007) on studying samples of sugarcane spirits from the South of Minas, the Jequitinhonha Valley and Zona da Mata.

As to the propyl alcohol content, it was verified that there was great variation among the samples, comprising the range from 12.24 to $51.74 \mathrm{mg} 100 \mathrm{~mL}_{\text {in }} \mathrm{aa}^{-1}$, in keeping with the results presented by Bogusz Júnior et al. (2006). According to the authors, the great variation of the content of that compound is due to the lack of technical knowledge about the fermentation process and distillation. Propanol is not produced during the fermentation by the alcohol yeasts, but may occur due to the secondary fermentations by the action of polluting bacteria.

Cleto and Mutton (1997) verified that the use of corn maize flour in the fermentation, a common practice among the informal producers, reduces the propanol concentration and reduces the total acidity of the drink, thus causing improvement in its quality. Those authors also concluded that the corn contains approximately $0.39 \%$ threonine and that the increase of that amino acid in the fermentation can influence the regulation processes of the propanol biosynthetic route.

Among the higher alcohols, the isoamyl alcohol is predominant in the samples and in the other alcoholic drinks, such as wines, beers, rum, whiskey and cognac, followed by the isobutyl alcohols and propyl (NÓBREGA, 2003). The isoamyl alcohol odor threshold value in water, $1000 \mu \mathrm{g} \mathrm{L}^{-1}$, is relatively high. Therefore, it is important to take into consideration that the odor characteristics of the volatile compounds depend on their concentrations, so that very high amounts can modify odor characteristics, considered by the scientific literature in the threshold of "pleasant", to "extremely unpleasant. This verifies that its formation occurs via the main higher alcohol formation route, that is the secondary catabolism in the sugar yeasts and amino acids, preferentially of the latter, during the alcohol fermentation. As such, several factors interfere in the formation of the related higher alcohols, almost exclusively, with the fermentation stage, like the weak activity of the ferment that causes a delay in the fermentation process. In the must, the alcohol content, the amino acid concentration, the $\mathrm{pH}$ and the temperature are important variables in the formation of those compounds. Furthermore, the prolonged time between fermentation and distillation also contributes to the increase of the higher alcohol concentration in the drink (BARCELOS et al., 2007).
In the detection and quantification limits of HPLC, values of 4.65 and $15.51 \mu \mathrm{g} \mathrm{L}^{-1}$, respectively were found. Figure 2 displays the chromatogram obtained for the EC standard. The average retention time obtained for EC was $13.3 \pm 0.1 \mathrm{~min}$, values near those found by (ANJOS et al., 2011; MACHADO et al., 2013; MASSON et al., 2014; SANTIAGO et al., 2014a; ZACARONI et al., 2011).

For the data described in Table 4, it is observed that the presence EC was detected only in Sample 01, with a concentration of $24.46 \pm 2.11 \mu \mathrm{g} \mathrm{L}^{-1}$, proven by the chromatogram depicted in Figure 3.

Figure 2 - Chromatogram of an EC solution at a concentration of $100.00 \mu \mathrm{g} \mathrm{L}^{-1}$

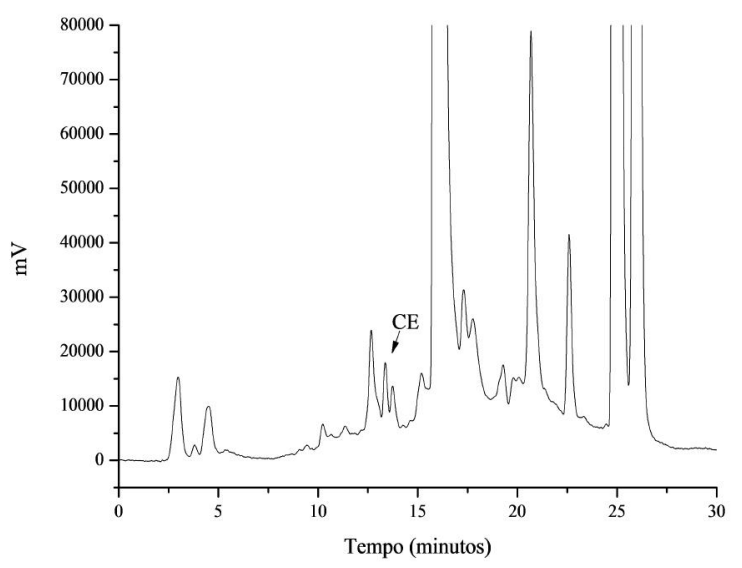

Table 4 - Average liquid chromatography performance

\begin{tabular}{cc}
\hline Samples & Ethyl carbamate $\left(\mu \mathrm{g} \mathrm{L}^{-1}\right)$ \\
\hline 01 & 24.46 \\
02 & $<\mathrm{DL}$ \\
03 & $<\mathrm{DL}$ \\
04 & $<\mathrm{DL}$ \\
05 & $<\mathrm{DL}$ \\
06 & $<\mathrm{DL}$ \\
07 & $<\mathrm{DL}$ \\
08 & $<\mathrm{DL}$ \\
09 & $<\mathrm{DL}$ \\
10 & $<\mathrm{DL}$ \\
11 & $<\mathrm{DL}$ \\
\hline
\end{tabular}

Note: <DL below detection limit 
Figure 3 - Chromatogram of sugarcane spirits sample 01

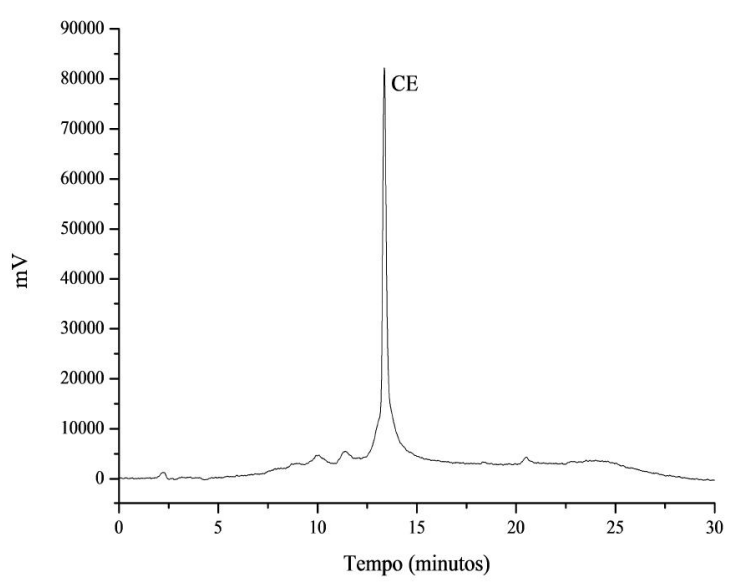

As Sample 01 is an aged sugarcane spirit, it is believed that the formation of that compound occurred in a gradual way during the storage period of the drink. Another factor that can increase or induce EC formation is the reaction between the ethanol and the urea formed by the degradation of nitrogenated precursors, intrinsic to the production process of the drink, the principal ones being the amino acids arginine, ornithine and citrulline. Besides these, other nitrogenated compounds have been studied as possible precursors for the formation of EC before and after the distillation process, as is the case of carbamyl phosphate and the cyanide ion (CARDOSO, 2013; MENDONÇA et al., 2016; SANTIAGO et al., 2014a; ZACARONI et al., 2011).

The organic sugarcane spirits are characterized by being produced from cane that did not undergo any type of synthetic fertilizer addition, mainly those that have nitrogen in their composition. It is believed that EC arises from substances added during the production stages of the drink. However, according to work of Machado et al. (2013), who used nitrogenated fertilizers in the cultivation of the cane to produce sugarcane spirits, varying the concentration of two nitrogen sources (urea and ammonium nitrate) in concentrations from 0 to 160 $\mathrm{kg}$ of $\mathrm{N} \mathrm{ha}^{-1}$, relates that there was no direct relationship between the increase of the fertilizer concentration and $\mathrm{EC}$ and its presence in the distillate, finding the maximum value of the pollutant at the concentration of $38.29 \mu \mathrm{g} \mathrm{L}^{-1}$ in the highest fertilizer addition.

Mendonça et al. (2016) determined the ethyl carbamate contents during the production processes involving different types of fermentation in which some yeasts contained nitrogen in their composition. The authors concluded that the sugarcane utilized had no influence on the formation of ethyl carbamate and that the concentrations encountered are in agreemente with the current legislation. However, the highest concentrations of ethyl carbamate were found in cachaça produced with yeast rich in nitrogen.

Andrade Sobrinho et al. (2009), affirm that the artisanal cane liquors (still) tend to present an EC content below that of the industrial liquors (column) due to the separation of the artisanal distillate into the fractions head, heart and tail, a fact that corroborates this work due to the fact that all of the samples were of artisanal production.

\section{CONCLUSION}

Among the eleven samples that were used to trace the physico-chemical and chromatographic profiles of organic sugarcane spirits, $36.40 \%$ of the samples were found to be outside the limits recommended by the MAPA with respect to the ester $(18.20 \%)$, copper $(9.10 \%)$ and solids $(9.10 \%)$ contents. These representative percentages demonstrate the fact that producers of these beverages are not observing the good manufacturing practices determined by law.

\section{ACKNOWLEDGEMENTS}

The authors acknowledge the support of the Conselho Nacional de Desenvolvimento Científico e Tecnológico (CNPq), the Fundação de Amparo a Pesquisa do Estado de Minas Gerais (FAPEMIG) and the Coordenação de Aperfeiçoamento de Pessoal de Nivel Superior (CAPES) for a PVNS fellowship (D. L. Nelson).

\section{REFERENCES}

ALCARDE, A. R.; SOUZA, P. A.; BELLUCO, A. E. S. Aspectos da composição química e aceitação sensorial da aguardente de cana-de-açúcar envelhecida em tonéis de diferentes madeiras. Ciência e Tecnologia de Alimentos, v. 30, p. 226-232, 2010.

ANDRADE SOBRINHO, L. G. et al. Teores de carbamato de etila em aguardentes de cana e mandioca. Parte II. Química Nova, v. 32, n. 1, p. 116-119, 2009.

ANJOS, J. P. et al. Identificação do carbamato de etila durante o armazenamento da cachaça em tonel de carvalho (Quercus $s p$ ) e recipiente de vidro. Química Nova, v. 34, n. 5, p. 874-878, 2011.

AGÊNCIA BRASILEIRA DE PROMOÇÃO DE EXPORTAÇÕES E INVESTIMENTOS. EUA reconhece cachaça como produto brasileiro. Disponível em: <http:// www.apexbrasil.com.br/portal/>. Acesso em: 18 jun. 2012. 
BARCELOS, L. V. F. et al. Teores de carbamato de etila e outros componentes secundários em diferentes cachaças produzidas em três regiões do estado de Minas Gerais: Zona da Mata, Sul de Minas e Vale do Jequitinhonha. Química Nova, v. 30, p. 10091011, 2007.

BOGUSZ JUNIOR, S. et al. Composição química da cachaça produzida na região noroeste do Rio Grande do Sul, Brasil. Ciências e Tecnologia de Alimentos, v. 26, n. 4, p. 793-798, 2006.

BRASIL. Ministério da Agricultura, Pecuária e Abastecimento. Instrução Normativa $\mathrm{n}^{\circ} 13$ de 29 de junho de 2005. Diário Oficial da União, Brasília, 30 de junho de 2005. Seção 1, p. 3.

BRASIL. Ministério da Agricultura, Pecuária e Abastecimento. Lei $\mathbf{n}^{\circ}$ 10.831, de 23 de dezembro de 2003. Dispõe sobre a agricultura orgânica. Brasília, 2003.

CARDOSO, M. G. Produção de aguardente de cana. 3. ed. Lavras: Editora UFLA, 2013. 340 p.

CLETO, F. V. G.; MUTTON, M. J. R. Rendimento e qualidade da aguardente de cana produzida utilizando fermento tratado com ácido e fubá de milho. Stab Açúcar, Álcool e Subprodutos, v. 16, n. 2, p. 38-40, 1997.

GABRIEL, A. V. M. D. et al. Effect of the spontaneous fermentation and the ageing on the chemo-sensory quality of Brazilian organic cachaça. Ciência Rural, v. 42, n. 5, p. 918925, maio 2012.

HARRIS, D. C. Análise química quantitativa. 7. ed. Rio de Janeiro: LTC, 2008.

MACHADO, A. M. R. et al. Determination of ethyl carbamate in cachaça produced from copper stills by HPLC. Food Chemistry, v. 138, n. 2/3, p. 1233-1238, 2013.

MADRERA, R. R.; VALLES, B. S. Determination of ethyl carbamate in cider spirits by HPLC-FLD. Food Control, v. 20, p. 139-143, 2009.

MAIA, A. B. R. A.; CAMPELO, F. A. P. Tecnologia da cachaça de alambique. Belo Horizonte: SEBRAE/MG: SINDBEBIDAS, 2006. 129 p.

MASSON, J. et al. Determination of acrolein, ethanol, volatile acidity, and copper in different samples of sugarcane spirits. Ciência e Tecnologia de Alimentos, v. 32, p. 1-5, 2012.

MASSON, J. et al. GC-MS analysis of ethyl carbamate in distilled sugar cane spirits from the northern and southern regions of Minas Gerais. Journal of the Institute of Brewing, v. 120, n. 4, p. 516-520, Sept. 2014.

MENDONCA, J. G. P. et al. Determination of ethyl carbamate in cachaças produced by selected yeast and spontaneous fermentation. Journal of the Institute of Brewing, v. 122, n. 1, p. $63-68,2016$.
MIRANDA, M. B. de et al. Perfil físico-químico de aguardente durante envelhecimento em tonéis de carvalho. Ciências e Tecnologia de Alimentos, v. 28, p. 84-89, dez. 2008. Suplemento.

MIRANDA, M. B.; HORI, J.; ALCARDE, A. R. Estudo do efeito da irradiação gamma (60CO) na qualidade da cachaça e no tonel de envelhecimento. Ciências e Tecnologia de Alimentos, v. 26, n. 4, p. 772-778, 2006.

NÓBREGA, I. C. C. Análise de compostos voláteis da aguardente de cana por concentração dinâmica do "headspace" e cromatografia gasosa-espectrometria de massas. Ciências e Tecnologia de Alimentos, v. 23, n. 2, p. $210-216,2003$

PARAZZI, C. et al. Avaliação e caracterização dos principais compostos químicos da aguardente de cana-de-açúcar envelhecida em tonéis de carvalho (Quercus sp.). Ciência e Tecnologia de Alimentos, v. 28, p. 193-199, 2008.

PARK, S. et al. Analysis of ethyl carbamate in Korean soy sauce using high-performance liquid chromatography with fluorescence detection or tandem mass spectrometry and gas chromatography with mass spectrometry. Food Control, v. 18, p. 975-982, 2007.

PEREIRA, N. E. et al. Compostos secundários em cachaças produzidas noEstado de Minas Gerais Ciênciase Agrotecnologia, v. 27, n. 5 , p. 1068-1075, set./out. 2003.

SANTIAGO, W. D. et al. Ethyl carbamate in the production and aging of cachaça in oak (Quercus sp.) and amburana (Amburana cearensis) barrels. Journal of the Institute of Brewing, v. 120, p. 507-511, Aug. 2014a.

SANTIAGO, W. D. et al. Comparação do perfil físico-químico de cachaças envelhecidas em tonéis de carvalho (Quercus sp) e amburana (Amburana cearensis). E-xacta, v. 7, n. 7, p. 17-29, 2014b.

SERVIÇO BRASILEIRO DE APOIO ÀS MICRO E PEQUENAS EMPRESAS. Potencial da cachaça brasileira. 2014. Disponível em: <http://www.sebrae.com.br>. Acesso em: 20 nov. 2015

SOUZA, L. M. et al. Teores de compostos orgânicos em cachaças produzidas na Região Norte Fluminense - Rio de Janeiro. Química Nova, v. 32, n. 9, p. 2304-2309, 2009.

VILELA, F. J. et al. Determinação das composições físicoquímicas de cachaças do Sul de Minas Gerais e de suas misturas. Ciências e Agrotecnologia, v. 31, n. 4, p. 1089-1094, jul./ago. 2007.

ZACARONI, L. M. et al. Caracterização e quantificação de contaminantes em aguardentes de cana. Química Nova, v. 34, n. 2, p. 320-324, 2011. 